\title{
Carmen Uriarte, Las Relaciones Hispano-Turcas durante la Guerra Civil Española 1936-1939, Madrid: Ministerio de Asuntos Exteriores Centro de Documentación y Publicaciones, 1995, 207 Sayfa, ISBN-10: 8487661491.
}

\author{
Berksan GÜLSOY' ${ }^{1}$
}

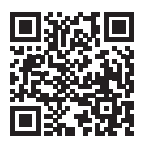

'Sorumlu yazar/Corresponding author:

Berksan Gülsoy (Doktora Öğrencisi), Marmara Üniversitesi, Türkiyat Araştırmaları Enstitüsü/Cumhuriyet Tarihi, İstanbul, Türkiye.

E-posta: gulsoyberksan@gmail.com ORCID: 0000-0001-6101-4770

Başvuru/Submitted: 10.02.2021 • Kabul/Accepted: 17.02.2021 • Online Yayın/Published Online: 02.04.2021

Atıf/Citation: Gülsoy, Berksan. “Las Relaciones Hispano-Turcas durante la Guerra Civil Española 1936-1939, adlı eserin tanıtımı. Türkiyat MecmuasıJournal of Turkology 31, 1 (2021): 487-490. https://doi.org/10.26650/iuturkiyat.900000

1923 yılı sonrası Türk-İspanyol ilişkileri hakkında İspanya' da araştırma yapanların sayısı oldukça azdır. Yapılan sayılı çalışmalardan bir tanesi Dr. Carmen Uriarte’ye aittir. Carmen Uriarte, İspanya'nın Bilbao Şehri’nde doğmuştur. Doktora çalışmasını Universidad del País Vasco'da (Bask Bölgesi Üniversitesi) yapmıştır. Doktora çalışması olarak Las Relaciones Hispano- Turcas Durante La Guerra Civil Española: 1936-1939 (İspanya İç Savaşı Sırasında Türk-İspanyol İlişkileri:1936-1939) başlıklı bir çalışma yapmıştır. 1989 yılında çalışmasını tamamlamıştır. Doktora tez danışmanı da Víctor Morales Lezcano'dur. Victor Morales'in de Türkiye hakkında bazı makaleleri vardır. İspanya Dışişleri Bakanlığı, 1995 yılında Carmen Uriarte'nin doktora tezini kitap olarak yayımlamıştır. Carmen Uriarte, 20 yıldan fazla Türkiye'de bulunmuştur. Ankara Üniversitesinde İspanyol dili ve kültürü hakkında dersler vermiştir. Bilbao'ya döndükten sonra Universidad del País Vasco'da Türk dili ve kültürüne yönelik dersler okutmuştur. 2009 yılından itibaren Türkiye'nin Bilbao'daki Fahri Konsolosu olarak görev yapmaktadır. 
Carmen Uriarte tarafindan kaleme alınan Las Relaciones Hispano- Turcas Durante La Guerra Civil Española: 1936-1939 (İspanya İç Savaşı Sırasında Türk-İspanyol İlişkileri: 1936-1939) isimli eser Türk-İspanyol ilişkilerini yansıtması açısından önemli bir çalışmadır. Türkçe ve İspanyolca kaynakların kullanılmış olması eserin kaynak değerini yükseltmektedir. Yapılan çalışma, bir tanıtım yazısı, bir ön söz, beş bölüm ve sonuçtan oluşmaktadır. Eserin sonunda kaynakça ve ekler bulunmaktadır. Tanıtım yazısını Ramón Villanueva Echeverría (1984-1990 yılları arasında İspanya'nın Ankara Büyükelçisi), ön sözü Uriarte'nin doktora tez danışmanı Víctor Morales Lezcano yazmıştır.

İlk bölümde (s. 1-17), Türkiye'nin coğrafi konumu, Türklerin Anadolu'ya gelişi, Osmanlı Devleti'nin yaşadığı tarihî süreç ve Türkiye Cumhuriyeti'nin kurulması gibi konular üzerinde durulmuştur. Türkiye'nin 90'lı yıllarda sahip olduğu siyasi sistem ve partiler ilk bölümde anlatılmıştır (s. 15-16). Aslında bu bölüm Türkiye tarihinin kısa bir sunumu olarak değerlendirilebilir. İkinci bölümde (s. 19-32), genel olarak Osmanlı ve Cumhuriyet dönemi basını hakkında bilgi verilmiştir. Uriarte, İspanya İç Savaşı sırasında Türk-İspanyol ilişkilerini anlatırken dönemin Türk basınından yararlanmıştır. Bu nedenle ikinci bölümde Osmanlı döneminden başlayarak Cumhuriyet dönemine kadar Türk basınının gelişiminden bahsetmiştir. Osmanlı döneminde faaliyet gösteren basını anlattıktan sonra bölümün sonuna doğru Cumhuriyet Rejimi'nin doğuşundan bahsetmiş ve bu rejimi destekleyen basını anlatmıştır. 1923-1940 arası faaliyet gösteren günlük yayın yapan ya da günlük yayın yapmayan resmî, özel gazete ve dergilerin istatiksel bilgilerini de vermiştir (s. 28-29).

Üçüncü bölümde (s. 33-49), yazar çeşitli diplomatik görevlilerle yaptığı mülakatları anlatmıştır. Onlardan elde ettiği bilgilere göre İspanya İç Savaşı'nda Türk bakışını anlamaya çalışmıştır. Madrid'deki Türk Büyükelçiliğinde kavaslık görevi yapmış olan Mustafa Topaloğlu ile bir röportaj yapmıştır. Topaloğlu, savaş sırasında 700 tane mültecinin Zurbano Sokağı'nda bulunan Türk Büyükelçiliğine sığındığını söylemiştir. Mülteciler, 250 kişilik kapasitesi olan Karadeniz isimli vapur ile İtalya üzerinden Türkiye’ye gönderilmek istenmiştir. Gemi İtalya’ya vardığında mülteciler Türkiye’ye devam etmek istememişler ve bir İtalyan teknesiyle İtalya'yı terk ederek Cadiz'e gitmişlerdir (s. 40-41). Mülteciler konusunda Türkiye bu şekilde bir yardımda bulunmuştur. Uriarte, Madrid Büyükelçiliği yapmış olan Zeki Kuneralp ile de bir röportaj yapmıştır. Kuneralp, İspanya'daki Cumhuriyet Hükümeti'ne Türkiye'nin fazla sempati beslemediğini, İspanya İç Savaşı sırasında ilişkilerin değiştiğini ve tarafsız bir politika izlendiğini belirtmiştir. Türkiye'den savaşa katılan çok fazla gönüllü olmadığını, Tan Gazetesi'nden Zekeriya ve Sabiha Sertel'in Cumhuriyetçileri, Cumhuriyet Gazetesi’nden Fevzi Togay’ın Falanjistleri desteklediğini anlatmıştır. Savaş sonrasında Türkiye'nin Franco Rejimi’yle ilişkiler kurduğunu da ifade etmiştir (s. 44-45). Uriarte, Topaloğlu ve Kuneralp dışında Ankara'daki İspanya Büyükelçiliğinde görevli Ercole Michelini, Cumhuriyet Gazetesi'nin sahibi Yunus Nadi Abalığlu'nun oğlu Nadir Nadi Abalıoğlu, İstanbul'daki Hahamlığın protokol şefi Haim Kohen ve Portekiz İstanbul Fahri 
Konsolosu Jacques José Abravanel ile de görüşmeler yapmıştır (s. 41-48). Bu isimlerin temel özelliği İspanya İç Savaşı sırasında Türkiye'de bulunmalarıdır. Yazar, onların perspektifinden Türkiye'nin savaşa karşı tutumunu yansıtmak istemiştir.

Kitabın en kapsamlı bölümü dördüncü bölümdür (s. 51-152). Yazar dördüncü bölümü iki parça hâlinde kaleme almıştır. Türk Dışişleri Bakanlığı Arşivi’nin açık olmasına karşın düzenlenmeye ihtiyacı bulunduğunu söyleyen Uriarte, Türk basınını kullanarak Türk Hükümeti’nin görüşlerini yansıtmak istemiştir. Bu bağlamda Ulus Gazetesi’ni kullanmıştır. Çünkü Ulus Gazetesi, İspanya İç Savaşı sırasında tek parti iktidarının yayın organı gibi hareket etmiştir. Uriarte, Ulus dışında İstanbul ve Ankara'da yayın yapan bazı gazetelerden de yararlanmıştır (s. 51). Bu gazeteler şunlardır: Türk Dili, Yeni Asır, Açık Söz, Akşam, Beyoğlu, Cumhuriyet, Haber, İstanbul, Kurun, Vakit, Son Posta, Son Telgraf, Tan, Yeni Sabah.

17 Temmuz 1936 tarihinde İspanya'da başlayan askerî ayaklanmadan sonra Türk basını gün gün yaşanan gelişmeleri aktarmıştır. Uriarte, gazetelerde çıkan haberleri kronolojik bir şekilde kitabında anlatmıştır. Bu haberlerden bir tanesi 5 Ağustos 1936 y1lında Ahmet Emin Yalman tarafından yazılmıştır. "Yeni Hasta Adam” başlığında yazısı çıkmıştır. Yalman, bu ifadeyi kullanarak İspanya'nın küçük düşürülmesinin amaçlanmadığını ancak yıllardır kargaşa ortamında yaşayan bir ülkeye hasta adam gözüyle bakılması gerektiğini ifade etmiştir (s. 61). 1937 yılının Ekim ayından itibaren savaş Falanjistlerin lehinde ilerlemektedir ve Türk Hükümeti politikasını buna göre belirlemiştir (s. 115). 1 Mart 1938 tarihinden itibaren Türk Hükümeti, Falanjist Burgos Hükümeti'ni fiilen tanımıştır. Gazetelerde bu durum yorumsuz verilmiştir (s. 123-127).

İspanya İç Savaşı süresince Türkiye tarafsız kalmayı amaçlamıştır. Uriarte, Türkiye'nin tarafsızlık politikasını başarıyla yürüttüğünü belirtmiştir. İsmet İnönü Cumhurbaşkanı olduktan sonra Türk dış politikasında ufak değişiklikler yaşanmıştır. Burgos Hükümeti’ne Türkiye tarafından uçak satıldığı iddia edilmiş ancak olay daha sonra kapanmıştır. Çünkü Türk Hükümeti'nde üst düzey görev yapan hiç kimse olaya karışmamıştır. İspanya İç Savaşı bittikten sonra Türkiye, Avrupa'da gelişmelerin nasıl devam edeceğini izlemiştir. İtalya'nın, İspanya'dan birliklerini çekmeyerek İngiltere ile yaptığı antlaşmaya uymayacağını ve bunun sonucunda İtalya’nın İngiltere ve Fransa ile karşı karşıya geleceğini Türkiye öngörmüştür. Türk basınının genelinde şöyle bir düşünce hâkimdir: Savaş sonrası İspanya'nın ülkeyi yeniden düzenlemek için İngiltere ve Fransa'nın yardımına muhtaç kalacağını, dolayısıyla İspanya'nın Avrupa için bir problem yaratmayacağı düşünülmüştür. Cumhuriyetçileri destekleyen Tan ve Haber gazeteleri dışında basının geneli Franco'yu İspanya'nın yeni temsilcisi olarak görmüştür. Ulus Gazetesi’ne göre Franco faşist değil gelenekçidir. Türk basını, İspanya İç Savaşı'ndan en karlı çıkan ülke olarak Almanya'yı görmüştür. Çünkü İtalya'nın savaş boyunca yaptığı yardımlardan dolayı gücü azalmış ve Orta Avrupa'daki gücünü Almanlar lehine kaybetmiştir. Bu durum İtalya'nın ekonomik gücünü kaybetmesine neden olmuştur. Dolayısıyla Almanya, İtalya karşısında güç kazanmıştır (s. 151-152). 
Uriarte kitabın son bölümünde (s. 153-182), Türkiye-İspanya ilişkilerini diplomatik açıdan ele almıştır. Archivo Embajada de España en Ankara (İspanya'nın Ankara Büyükelçiliği Arşivi) ve Archivo del Ministerio de Asuntos Exteriores (İspanya Dişişleri Bakanlığı Arşivi) arşivlerden elde ettiği malzemeleri yazar son bölümde kullanmıştır. Bu belgelerden yazarın ulaştığı bilgiler şunlardır:

1. Türk Hükümeti İspanya İç Savaşı sırasında tarafsız bir politika izlemiştir.

2. Franco Hükümeti'nin savaşı kazanmaya yakın olduğu anlaşıldığında, Türk Hükümeti fiilen Franco Hükümeti'ni tanımıştır. Yazar bu durumu, II. Dünya Savaşı sırasında Türk Hükümeti’nin izlediği politikaya benzetmektedir. II. Dünya Savaşı'nın bitmesine az bir süre kala Türkiye, Almanya'ya savaş ilan etmiştir. Bu kâğıt üzerinde yapılan bir eylemdi. İspanya İç Savaşı boyunca Türkiye hem Cumhuriyetçilerle hem de Franco destekçileriyle ilişkisini sürdürmüştür. Savaşın sonucu belli olmaya başladığında, Türkiye pozisyonunu ona göre almıştır. Atatürk’ün ölümünden sonra İsmet İnönü de büyük oranda Atatürk dönemine benzer bir dış politika izlemiştir. Tarafsızlık politikası hem İspanya İç Savaşı'nın hem de II. Dünya Savaşı'nın temel dış politikası olmuştur.

3. 28 Şubat-1 Mart 1938 tarihinden sonra Türkiye, Franco Hükümeti'ni fiilen tanımıştır. Bunun nedeni, Francocu Hükümet'in İspanyol topraklarının yarısını yönetmesiydi. Cumhuriyetçi Hükümet'in artan düzensiz davranışları da bu kararın alınmasında etkilidir (s. 180-181; 186).

Sonuç olarak yazar, İspanya İç Savaşı’nın ilk yıllarında (1936-1937) ve savaşın sonuna doğru Türk toplumunun savaşa gösterdiği ilginin en üst seviyede olduğunu ancak gösterilen ilginin çok az incelendiğini belirtmiştir. Eserin kaynakçası değerlendirildiğinde İspanyol arşivlerinin ve Türk basınının kullanıldığı anlaşılmaktadır. Bu bağlamda kaynak değerinin kıymeti artmaktadır. 20. yüzyıldaki Türk-İspanyol ilişkilerini anlatan eser sayısı oldukça azdır. Dolayısıyla Carmen Uriarte'nin kaleme aldığı bu eser, modern dönem Türk-İspanyol ilişkilerini çalışacaklar için yol gösterici niteliktedir. 